S. G. Gendler ${ }^{1}$, orcid.org/0000-0002-7721-7246,

M. V. Tumanov', orcid.org/0000-0003-3795-1005, L. Yu. Levin ${ }^{2}$, orcid.org/0000-0003-0767-9207
1 - Saint Petersburg Mining University, Saint Petersburg, Russian Federation, e-mail: gendler sg@nuos.pro 2 - Mining Institute of the Ural Branch of the Russian Academy of Sciences, Perm, Russian Federation

\title{
PRINCIPLES FOR SELECTING, TRAINING AND MAINTAINING SKILLS FOR SAFE WORK OF PERSONNEL FOR MINING INDUSTRY ENTERPRISES
}

Purpose. To reduce the risks of accidents and injuries on the basis of vocational selection of the stuff for work in the mining industry, as well as training and maintaining their skills of safe work.

Methodology. To solve the problems considered in the article, the following were used: analysis of information from scientific and technical sources on the influence of psychophysiological factors on occupational injuries; correlation-regression analysis of statistical data on occupational injuries; experimental research on efficiency of miners' work in laboratory and mine conditions at various physical activities.

Findings. The article substantiates the role and necessity of conducting professional psychophysiological selection procedures for mining workers, monitoring their functional state. The methodology of professional psychophysiological selection procedures, innovative training and behavioral audit is proposed in order to increase the injury protection of workers. Innovative ways of training and maintaining the safe working skills of miners are explored. The role of modern gadgets with installed applications for assessing the severity of physical work in terms of heart rate is investigated.

Originality. The novelty of this study is to substantiate a comprehensive approach to the preventive precautions against occupational injuries in the mining industry at the stages of personnel selection, training and further control of the consequences of production activities.

Practical value. Principles are developed for selecting, training, and maintaining skills for the safe work of personnel for the mining industry.

Keywords: human factor, functional state, professional selection, personnel training, injury risk, accident prevention, behavioral audit

Introduction. Ensuring workplace safety requirements during production activities is one of the priority tasks for many countries. The efficiency of production and the economic indicators of products largely depend on the successful solution of issues of ensuring labour safety and reducing industrial injuries. Neglect or insufficient attention to health and safety issues, in addition to technical and economic damage, can lead to serious social impact.

Labour safety problems are most relevant for the mining industry enterprises, which, in most cases, are classified as hazardous production facilities. If the risk of industrial injuries, calculated as the ratio of the number of injuries per year to the total number of workers, is taken as an indicator of occupational safety then the risk of injuries for the mining industry exceeds the average risk for other industries in Russia by 4-5 times.

Reducing the risk of industrial injuries is possible with the integrated use of selection, training and maintenance of skills for safe work of personnel in conditions with hazardous and harmful environmental factors and the production process. In the overwhelming majority of cases, the occurrence of dangerous situations leading to injuries is associated with insufficient prompt response to their causes, which determines the need to identify such qualities as responsiveness, mental stability, and efficient response in workers.

In the absence of such qualities, it is necessary to develop them in future workers as a result of the training process or on special simulators, or in conditions close to the working. Another side of the prevention of injuries is the implementation of operational control of the labour activity of miners at all stages of the production process.

The urgent problem of ensuring the safety management of the mining industry in Russia, preserving the health and longevity of miners should be solved based on modernisation of standard technologies for their professional selection, training and maintaining skills for safe work. Ensuring a basic level of safety in the daily activities of miners is a prerequisite for maintaining high efficiency in the mining industry. The main

(C) Gendler S. G., Tumanov M.V., Levin L. Yu., 2021 task of safety management in the mining industry should be considered the prevention of accidents and injuries, the main cause of which is the so-called "human factor", defined as a set of individual properties and qualities of a person, manifested when interacting with mining systems in specific working conditions.

Literature review. Minimising the risks of industrial injuries and occupational diseases requires the creation of safe working conditions, the concept of which is closely related to the concept of "safe work" (activity). Safe work can be represented as a purposeful production activity to perform work functions with the condition of observing safety rules and having a low probability of developing acute and chronic health disorders of the employee. Consonant, but not identical ideas are considered in the paper by A. Ray and D. Proven [1]. The authors state: "The work of ensuring security consists of activities carried out in organisations whose purpose is the management of security. Safe work is different from operational work, which directly achieves the main objectives of the organisation. Safe work also differs from "occupational safety", which consists in preventing injuries and unfavourable working conditions".

In a number of studies [2, 3], the permanent problem of preserving occupational health and longevity, as well as a high level of working capacity of persons exposed to a high risk of exposure to extreme environmental factors in the process of daily activities, is highlighted $[4,5]$. This is due to the fact that the number of victims of various social, natural, and manmade disasters does not tend to decrease, but exists at a high level and the importance of the security problem does not diminish [6, 7].

At present, there is a clear understanding that personnel safety problems are not only of narrowly specialised importance in the labour protection system $[8,9]$. It is the integrated system of ensuring production safety, taking into account close attention to the various characteristics of the "human factor", that is the key element that creates a competitive advantage for modern companies. Since considerable savings in financial resources can be achieved by reducing the severity and frequency 
of injuries sustained at workplaces, and improving safety of working conditions serves as a reliable guarantee of reducing the number of accidents $[10,11]$.

Methods. The initial materials used in the study were adopted based on Rostechnadzor statistical data on labour protection and industrial safety in the mining industry, including the functional characteristics of miners when performing production operations in mine and laboratory conditions.

A set of methods was used in the study, including the analysis of information from scientific and technical sources on the influence of psychophysiological factors on industrial injuries; correlation and regression analysis of statistical data on industrial injuries. In addition, such special methods were applied as modelling, questionnaire, interviewing, experimental studies on the efficiency of miners in laboratory and mine conditions under various physical loads. In addition, system analysis and comparison were used. The methodological basis was the proposed integrated safety management system, taking into account the "human factor" as a backbone. The activities of the proposed system consist of successively applied modules:

- selection of personnel based on the criterion of neuropsychic stability;

- conducting training in safe methods of activity with control of effectiveness and regular training;

- monitoring of heart rate (HR) and behavioural safety audit taking into account the place, time and type of activities that exceed the normative indicators.

Results. The main task of managing the safety of the mining industry should be considered the prevention of accidents and injuries, the main cause of which is the so-called "human factor". The human factor is defined as a set of individual properties and qualities of a person, manifested when interacting with mining systems in specific working conditions. The management of "human factor" should be based on the analysis of the "personality factor" dynamics at various stages of production activity. That is, identification of the necessary psychophysiological qualities when hiring personnel, during continuous training of miners, and also the organisational and technical consequences of its impact on the safety of labour process.

Analysis of accidents and injuries in the mining industry in Russia shows that the "human factor" should be considered their main cause, as a factor of the totality of individual properties and qualities, manifested when interacting with technical systems in specific working conditions [12, 13]. A whole range of production factors constantly affect the personnel of the mining industry during their daily professional activities, contribute to unfavourable changes in the functional state of workers, causing tension in the regulatory systems, causing overwork and thereby reducing the reliability of personnel, contributing to the occurrence of traumatic situations at various stages of production activity.

At the same time, it was found that one of the main causes of injury of workers in the mining industry is disruption of technological processes. The causes of injuries and accidents are distributed according to the data of the regulatory authorities as follows:

- $27 \%$ - violations of production technology;

- $27 \%$ - incorrect work organisation;

- $18 \%$ - ineffectiveness of production control;

- $18 \%$ - violations of labour discipline;

- $10 \%$ - low level of knowledge of the safety regulations and rules.

Thus, the main measure for increasing the level of industrial safety at coal enterprises is to increase the role of production control. That is, responsibility for the state of industrial safety of all sections of the production process - from top managers to direct executors [13, 14]. A systematic review of lost time injuries (LTI) in the US mining industry has shown that predictive factors for LTI include: slips and falls, electrical injuries, unsafe application of mining equipment, work in underground mines, age and professional experience of worker [15].

The professional activity of specialists in the mining industry is associated with increased neuropsychic workloads and stress. A decrease in the level of neuropsychic regulation due to fatigue and overwork leads to asthenic manifestations. As a result, the capabilities of the main regulatory systems decrease, reducing the level of the body's functional reserves. Changes in the functional state of the body are early predictors of the tension of the body's regulatory systems in the process of intense and responsible professional activity performed with proper quality. It is early diagnosis and quick restoration of the physiological reserves of the body that can significantly improve the labour safety and is a leading factor in ensuring reliability of professional activities in the mining industry. A targeted complex effect on a person to increase safety can be achieved by various preventive measures. Such measures include: unscheduled instructions, additional training in the regulations and rules of safe work underground, additional psychological trainings to develop the skill of safe behaviour in a hazardous environment.

According to S. G. Gendler and A. M. Grishina [16], one of the main factors affecting the level of injuries and accidents is the work experience (Fig. 1), which shows correlation dependence of the risk of general injuries and work experience based on data on industrial injuries and accidents at SUEKKUZBASS JSC for the period 2008-2017.

One of the reasons for the high level of injuries at the beginning of production activity is the personnel's low qualifications due to the lack of stable skills for performing underground work. At the same time, one year of production activity, as a rule, is enough to acquire the required qualification level, which guarantees the mastering of the profession [16]. According to the study, the individual psychophysiological characteristics of miners can and should be taken into account even before the start of production activities, at the stage of personnel selection.

Thus, it becomes obvious that many violations of safety requirements at the workplace are partially related to the fact that the influence of the "human factor" is associated with individual differences in the workers' reactions to similar or identical environmental factors. It is the individual differences in basic physiological indicators that largely determine the following: in the same working conditions, the level of functional state, efficiency and safety of work, work capacity in people is not the same. Therefore, there are differences in the state of so-called practical (professional) health.

Substantiation of the requirements for the personnel selection in the mining industry. Working underground requires special attention to health and safety management. One of the methods to improve the reliability and safety of personnel in mines is professional selection procedures. Unfortunately, there is evidence that professional selection is formal in nature and does not take into account the technical features of mining and the type of activity (specialty) of the worker, i. e., environ-

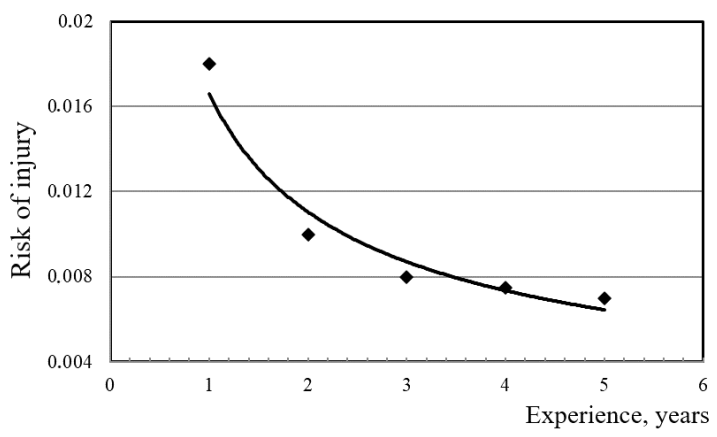

Fig. 1. Dependence of the risk of injury of miners on the length of employment 
mental conditions external to the employee that impose special requirements on the level of occupational health and professional suitability.

According to study by G. V. Kozlova [17], carried out in SUEK-KUZBASS JSC, about 15-18\% of employees of this subdivision of SUEK JSC, due to their psychophysiological qualities, perform their work duties with great psycho-emotional stress; $6-11 \%$ of employees of the enterprise do not able to comply with applicable regulations and safety rules in dangerous situations. Thus, the results of testing the miners using the mine escape breathing apparatus showed the following. Due to the lack of proper breathing skills in dangerous situations, $57 \%$ of the tested miners ended the resource of the escape apparatus prematurely; $23 \%$ of miners stopped testing due to the appearance of negative sensations.

The organisation of the professional psychophysiological selection system should be based on the principles of complexity, objectivity, and dynamism of studying the physiological and regulatory systems of the human body, as well as individually personal characteristics in various working conditions. In this case, a significant role is assigned to assessing the reliability of the nervous system, which performs a regulatory function in the body and the characteristics of the individual's mental development.

The experience of the provision of medical and psychological assistance to military personnel in extreme working conditions indicates the possibility of identifying a number of areas, the implementation of which allows successfully solving the problems of preserving the health of miners [18]. This includes: a psychophysiological forecasting of the health of miners and the identification of the so-called "high risk" group, i.e., persons with low indicators of the adaptive potential of the personality, high anxiety, and a low level of neuropsychic stability; optimal distribution of persons with different levels of neuropsychic stability; training of selected specialists in safe working skills, support of the professional activities of miners by monitoring the physiological indicators of workers' health.

Therefore, it is possible to form groups of miners according to the criterion of neuropsychic stability and reliability. Here, the $1^{\text {st }}$ group will be represented by persons with the highest indicators of neuropsychic stability (NPS), while individual characteristics allow considering them as candidates for leadership positions. The $2^{\text {nd }}$ group is represented by candidates with high levels of NPS, suitable for work with a high level of injury risk. The $3^{\text {rd }}$ group has an insufficient level of neuropsychic stability and can be involved in auxiliary units with a low risk of injury. Persons referred to the last, $4^{\text {th }}$ group are not recommended for the mining activity, since they have pronounced symptoms of neuropsychic instability with a high risk of disruption of labour discipline and injury.

Psychophysiological forecasting of the occupational health of miners can be represented as a set of measures aimed at assessing the level of some individual and personal characteristics of miners. Such characteristics determine the possibility of successful adaptation to the working conditions (including extreme conditions) and, therefore, determine the risk of developing traumatic injuries, diseases and decrease in the efficiency of professional activity. This measure is carried out at almost all organisational stages and concerns the determination of the level of neuropsychic stability. It is necessary to involve labour protection specialists and medical advisors in the implementation of this measure.

Thus, a systematic approach to substantiating the selection principles should be based on an analysis of the relationship between individual and personal characteristics, indicators of the functional state of the body and the level of occupational health of miners at various stages of work. The chosen methodology and principles of organization of activities allow solving the tasks of labour protection and contributing to the development of a comprehensive system of safety measures aimed at maintaining the health and professional longevity of workers (Fig. 2).

Control criteria should cover all stages of the workflow:

- selection and training of personnel in specific working conditions;

- control over the implementation of the production process;

- conducting periodic, as well as off-schedule briefing on safety rules and regulations when working in underground conditions;

- increasing the motivation of workers to comply with safety regulations;

- monitoring of the functional state of miners, followed by prompt correction of early deviations from the normal state;

- restoration of the physiological reserves of the body of miners.

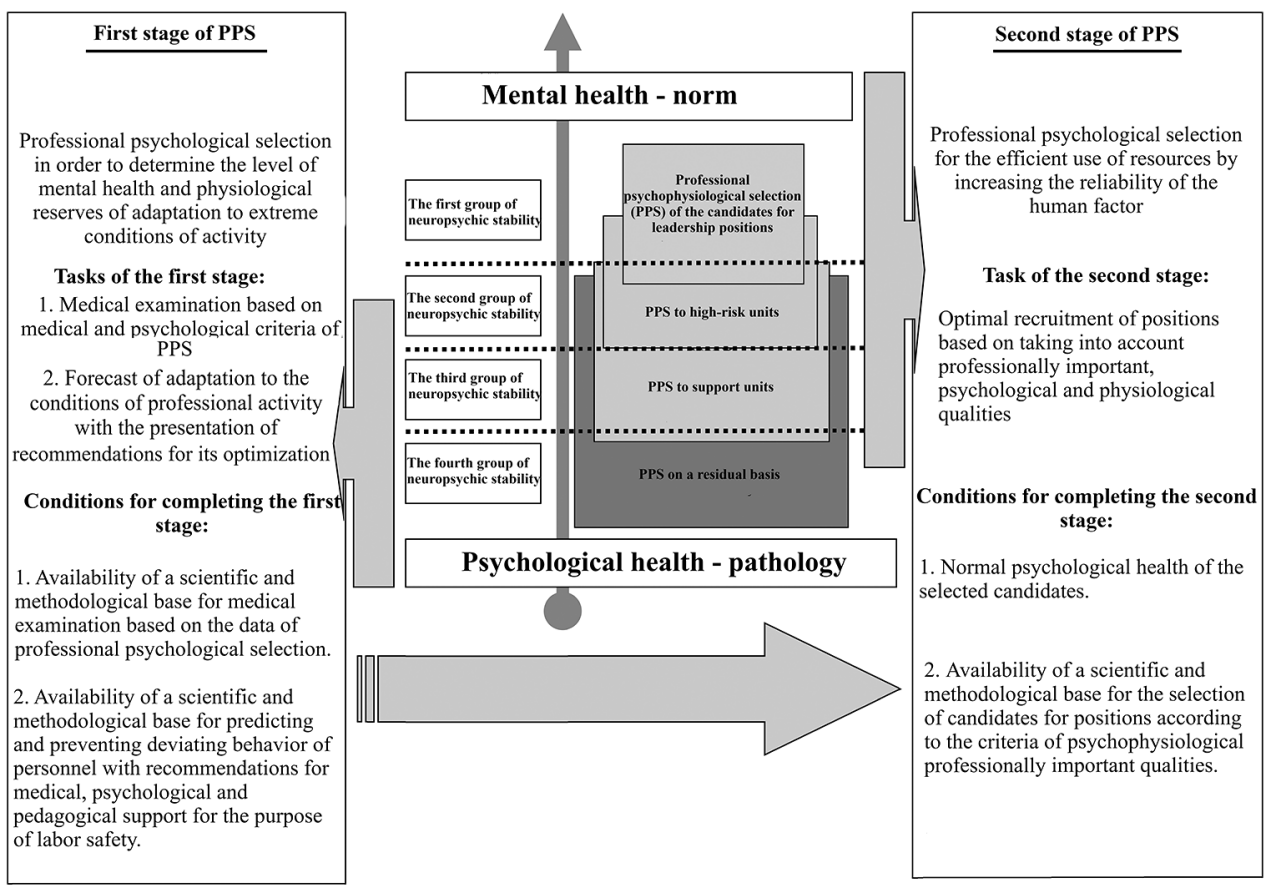

Fig. 2. The main elements of the system of professional psychophysiological selection (PPS) 
It can be argued that professional training of safe work skills of miners (PTSWS) can be represented by three main stages: the first stage is represented by training to increase the level of readiness and competence to safely perform professional activities in extreme conditions; the second stage is represented by periodic professional trainings to maintain an effective level of skills for safe work in extreme conditions; the third stage involves periodic behavioural monitoring to maintain effective levels of safe work skills and behaviour in extreme conditions. The tasks of the first stage of the PTSWS include: teaching safe techniques for performing professional activities, developing motivation and skills for safe work, forecasting the effectiveness and safety of professional activities with the presentation of recommendations for its optimisation (based on monitoring data of the functional state, testing and expert assessments). The tasks of the second stage of the PTSWS are represented by the development of stable patterns of professional behaviour that provide a reserve of skills for safe work in everyday conditions, development of stable patterns of behaviour and actions in extreme working conditions. The third stage of the PTSWS deals with the problem of optimal recruitment of miners based on the professionally important psychophysiological qualities (Fig. 3).

Gendler S. G., Grishina A. M. and Kochetkova E.A. [16] have analysed the complex of motor actions from the standpoint of biomechanics. Based on the visualisation of reference motor skills, miners' stable skills for performing technological operations have been developed. The visualisation of deviations from the standard actions of an expert with the necessary work experience allowed working out an innovative technology for quick and efficient training.

Kozlov G. V. [17] aptly notes that professional selection and training should include tests simulating an extreme situation, when paramilitary mine rescue units or auxiliary rescue teams have not arrived yet. The candidate's task is to demonstrate the skills of effectively solving the assigned task in an emergency situation, including tests with an assessment of the miner's performance with the escape breathing apparatus.
At the same time, the correspondence of the actual time of the miner's work in the escape apparatus to the maximum time set by the manufacturer was taken as an indicator for assessing the performance of miners. One of the reasons for the premature operation of the resource of the device is the lack of experience of the miners in its correct use, i.e., lack of proper breathing skills $[14,17]$.

Primary prevention of injuries and illnesses among workers is the cheapest, as it may sound, way to ensure the preservation of human and financial resources of the state. The development of secondary prevention based on modern medical technologies has a steady tendency towards an increase in cost. The orientation towards tertiary prevention, aimed at the rehabilitation of sick persons, is socially, ethically and economically less effective than systematic work in the field of primary (radical) prevention.

In the practice of workplace health and safety, it is quite relevant to study the primary health indicators, recognised by medical commissions as suitable for performing production activities. In this case, it is advisable to record direct indicators of physiological function before injury. Thus, it is possible to record critical changes in physiological indicators that indirectly indicate an increase in the risk of developing traumatic behaviour. The background values of various health parameters before injury and their unexpected changes may indicate that the employee is under the influence of working-environment factors that are inadequate to his functional capabilities.

For the purpose of the primary prevention of traumatic injuries, it is advisable to predict the injury to a specific person based on the available data characterising his functional state. It is usually assessed by health indicators defining the physiological functions, the main of them is heart rate. Assessment of the functional state of an employee before injury is more effective for the state and society, since it allows preventing injuries.

In all injured employees, in comparison with their noninjured colleagues, the recorded indicators of the functional state were significantly lower, which indicates the possibility of active identification and targeted implementation of preventive measures. This allows carrying out the primary prevention

\begin{tabular}{|l|}
\hline \multicolumn{1}{|c|}{$\begin{array}{c}\text { 1st stage of professional } \\
\text { training in safe work skills }\end{array}$} \\
Professional training in order to \\
increase the level of readiness \\
and competence to carry out \\
safe professional activities in \\
extreme conditions
\end{tabular}

\begin{tabular}{|l|}
\hline $\begin{array}{c}\text { 2nd stage of professional } \\
\text { training in safe work skills }\end{array}$ \\
$\begin{array}{c}\text { Periodic professional training to } \\
\text { maintain effective levels of safe } \\
\text { work skills and extreme } \\
\text { handling }\end{array}$ \\
Tasks of the 2nd stage: \\
$\begin{array}{l}\text { 1. Development of stable patterns of } \\
\text { behavior that provide a reserve of } \\
\text { skills for safe work in everyday } \\
\text { conditions. } \\
\text { 2. Working out stable patterns of } \\
\text { behavior and actions in extreme } \\
\text { conditions. }\end{array}$ \\
Conditions for completing the \\
2nd stage: \\
$\begin{array}{l}\text { 1. Optimal psychophysiological state of } \\
\text { health of workers. } \\
\text { 2. Availability of a scientific and } \\
\text { methodological base for the selection of } \\
\text { candidates for positions according to the } \\
\text { criteria of psychophysiological } \\
\text { professionally important qualities. }\end{array}$ \\
\hline
\end{tabular}

\begin{tabular}{|l|}
\hline $\begin{array}{c}\text { 3rd stage of professional } \\
\text { training in safe work skills }\end{array}$ \\
$\begin{array}{c}\text { Periodic behavioral monitoring } \\
\text { to maintain effective levels of safe } \\
\text { work skills and handling in } \\
\text { extreme conditions }\end{array}$ \\
Task of the 3rd stage: \\
1. Optimal staffing of positions \\
based on the account of the \\
professionally important, \\
psychological and physiological \\
qualities of personnel. \\
\\
Conditions for completing the 3rd \\
stage: \\
1. Optimal psychophysiological state of \\
health of workers. \\
2. Availability of scientific and \\
methodological base of "risk group" of \\
violation of safe work in everyday and \\
extreme conditions of professional \\
activity.
\end{tabular}

Fig. 3. The main elements of the system of professional training of safe work skills (PTSWS) 
of injuries of personnel with identified deficiencies in the indicators of the functional state. At the same time, people who consciously choose a healthy lifestyle, control their health level and are engaged in active prevention prefer to use simple and accessible technical systems for monitoring the functional state in terms of heart rate.

One well-studied metric is heart rate variability (HRV). Modern gadgets with installed applications perform a simple analysis of the signals from the heart into a variety of useful data on the functioning of the body, on which conclusions are drawn about the work of central and autonomic regulation. The use of this indicator began in the 1960s with the beginning of the era of manned astronautics. It was developed as a remote non-invasive way to measure the influence of stress on the body's regulation system, to assess the functional state, the risk of developing pathological processes and other parameters during telemetric monitoring of a person's state and their performance in space flight. At the same time, it is known that the limits of heart rate change are the main physiological criterion for the severity of physical work at its individual stages. According to the magnitude of changes in values observed during work, four categories of changes in physiological indicators (primary health indicators) are established: small, moderate, severe, very severe (Table 1).

In addition to physiological parameters of severity and intensity of the work performed, a complex of symptoms of fatigue can be recorded, expressed in points. The response of the heart rate to the work performed and its comparison with the severity of subjective signs of fatigue can be used to substantiate work and rest regimes as preventive measures aimed at reducing the level of injuries and occupational diseases of specialists.

The functional state of the human body is a systemic response of regulatory systems, psychophysiological and physiological functions that ensure the effectiveness of specific professional activities. The functional state is the result of a complex systemic reaction of the human body, dynamically changing in the process of regulation of their labour activity and due to the interaction of the functional systems of the body. Thus, the information provided by heart rate indicators is a reliable predictor of the development of premorbid conditions even before the onset of a disease or injury.

The personal heart rate monitoring system includes a chest strap that records your heart rate and the Polar Beat smartphone application. Cell phones, photo, video and audio equipment, with the exception of special-purpose equipment, are not allowed into the mine. Therefore, the sensor is attached directly to the body of an employee in the mine, and control from a smartphone is carried out by a specially trained person on the surface.

In the process of performing professional activities by an employee throughout the entire work shift, the heart rate is continuously recorded. At the same time, the processing programme records the changes in the pulse at each moment of time and distributes them into five zones of regulation, where the maximum fifth zone, marked in red, reflects the maximum increase in heart rate relative to the state of rest (zones 1-2), which corresponds to hard and strenuous work. At the same time, the correspondence of the five zones of increase in heart rate in the Polar Beat application to the presented criteria for changes can be represented as follows (Table 2).

The introduction of this system allows registering situations of potential danger for a person (near-miss). That is, when the functional reliability of physiological regulation systems is at maximum stress to ensure proper performance, without disruptions, failures and injuries. With a continuing increase in the load, there is a high risk of disruption of the function of the heart rate regulation systems, since the state of the body is in high unproductiveness, as a result of which the risk of injury increases [3, 19].

The heart rate monitoring system helps to conduct a behavioural safety audit of an employee, identifying a potentially
Assessment of the severity of physical work in terms of heart rate

\begin{tabular}{|l|c|c|c|c|}
\hline \multirow{2}{*}{$\begin{array}{c}\text { Physiological } \\
\text { indicator }\end{array}$} & \multicolumn{4}{|c|}{ Tests for changes } \\
\cline { 2 - 5 } & small & moderate & severe & very severe \\
\hline Heart rate & $75-100$ & $101-120$ & $121-150$ & Over 150 \\
\hline
\end{tabular}

Table 2

Assessment of the severity and intensity of work by heart rate and zones of the Polar Beat application

\begin{tabular}{|c|c|c|c|}
\hline \multicolumn{4}{|c|}{ Criteria for heart rate changes } \\
\hline small & moderate & $\begin{array}{c}\text { severe } \\
\text { (strong) }\end{array}$ & $\begin{array}{c}\text { very severe } \\
\text { (very strong) }\end{array}$ \\
\hline $75-100 \mathrm{bpm}$ & $101-120 \mathrm{bpm}$ & $121-150 \mathrm{bpm}$ & over 150 bpm \\
\hline up to100\% & $(101.3-118.8 \%)$ & $(120-137 \%)$ & over 137\% \\
\hline $\begin{array}{c}\text { zone 1-2 } \\
\text { (grey and blue } \\
\text { indication) }\end{array}$ & $\begin{array}{c}\text { zone 3 (green } \\
\text { indication) }\end{array}$ & $\begin{array}{c}\text { zone } 4 \\
\text { (yellow } \\
\text { indication) }\end{array}$ & $\begin{array}{c}\text { zone 4 (red } \\
\text { indication) }\end{array}$ \\
\hline
\end{tabular}

dangerous place, the percentage of work time in the "red" zone in terms of heart rate indicators and the types of work that cause these changes in regulation [20]. This allows for the labour protection service to timely identify and record areas and types of work that carry a potential risk of injury to an employee. In addition, this system allows saving the company's funds (payments of disability benefits, payment for outpatient treatment, and so on), preventing detected dangers and promptly sending an employee for a medical examination.

Conclusions. One of the central issues in the development of the "human factor" management procedure should be considered the choice of management criteria. These criteria should cover all stages of the workflow.

Underground personnel should periodically practice stable patterns of professional behaviour that provide a reserve of skills for safe work in everyday conditions. It is also necessary to practice stable patterns of behaviour and actions in extreme working environment, with an orientation during the training process to maximise coincidence with the value of the indicator selected as "reference".

The choice of priority areas for managing the "human factor" should be based on the analysis of the "personality factor" dynamics at various stages of production activity. From identifying the necessary psychophysiological qualities of personnel during selection to their continuous training, carried out in order to maintain professional activities of workers.

An integral part of the selection and rational distribution system is to conduct periodic trainings to develop skills for safe work in extreme situations. An additional element of assessing the preparation efficiency should be practical skills to ensure their own safety.

Particular attention should be paid to miners with a short experience of professional activity (up to a year), since this category of workers do not have reliably developed skills, which reduces their safety.

\section{References.}

1. Rae, A., \& Provan, D. (2019). Safety work versus the safety of work. Safety Science, 111, 119-127. https://doi.org/10.1016/j. ssci.2018.07.001.

2. Cherepovitsyn, A.E., Ilyinova, A.A., \& Evseeva, O.O. (2019). Stakeholders management of carbon sequestration project in the state - business - society system. Journal of the Mining Institute, 240, 731-742. https://doi.org/10.3189/ PMI.2019.6.731.

3. Fainburg, G. Z. (2018). The occupational safety and health system: key problems and solutions. Human Resources Man- 
Agement, 9(3), 58-65. https://doi.org/10.29141/2218-50032018-9-3-10.

4. Filimonov, V.A., \& Gorina, L. N. (2019). Development of an occupational safety management system based on the process approach. Journal of the Mining Institute, 235, 113-122. https://doi.org/10.31897/PMI.2019.1.113.

5. Gridina, E.B., Pasynkov, A.V., \& Andreev, R.E. (2019). Comprehensive approach to managing the safety of miners in coal mines. In Innovation-Based Development of the Mineral Resources Sector: Challenges and Prospects: Proceedings of the XITH Russian-German Raw Materials Conference, (pp. 85-94). Potsdam, Germany. Retrieved from https://iopscience.iop.org/ article/10.1088/1757-899X/560/1/012067.

6. Gridina, E. B., \& Andreev, R. E. (2017). Mathematical modeling based on CFD method of wind currents in combined working out of the Olenegorsky pit in the FlowVision software package. International Review on Modelling and Simulations, 10(1), 62-69. https://doi.org/10.15866/iremos.v10i1.11101.

7. Kovshov, S., Istomin, R., Nikulin, A., \& Sotiriu, A. (2014). Industrial injuries appraisal in mines of JSC "SUEK Kuzbass". Advanced Materials Research, 1001, 414-420. https:// doi.org/10.4028/www.scientific.net/AMR.1001.414.

8. Kretschmann, J., Plien, M., Nguyen, T.H.N., \& Rudakov, M. (2020). Effective capacity building by empowerment teaching in the field of occupational safety and health management in mining. Journal of Mining Institute, 242(2), 248-256. https://doi.org/10.31897/PMI.2020.2.248.

9. Kuletsky, V. N., Zhunda, S. V., \& Dovgenok, A. S. (2020). Organization of ensuring the safety of production processes in a coal mine in the face of an increase in the capacity of mining equipment. Ugol, 2, 35-40. https://doi.org/10.187796/00415790-2020-2-35-40.

10. Litvinenko, V.S. (2019). Digital economy as a factor in the technological development of the mineral sector. Natural Resources Research, 28(113), 1-21. https://doi.org/10.1007/ s11053-019-09568-4.

11. Litvinenko, V. S., Tsvetkov, P. S., \& Molodtsov, K. V. (2020). The social and market mechanism of sustainable development of public companies in the mineral resource sector. Eurasian Mining, 1, 36-41. https://doi.org/10.17580/em.2020.01.07.

12. Artemiev, V.B., Lisovskiy, V.V., Tsinoshkin, G. M., \& Kravchuk, I.L. (2018). SUEK on the way to "zero traumatism”. Coal, 8(1109), 71-75. https://doi.org/10.18796/00415790-2018-8-71-75.

13. Ivanov, Yu. M. (2018). Comprehensive labour safety at the enterprises of SUEK-KUZBASS. Mining Information and Analytical Bulletin, 11(49), 326-334.https://doi.org/10.25018/02361493-2018-11-49-326-334.

14. Musharraf, M., Khan, F., \& Veitch, B. (2019). Modeling and simulation of offshore personnel during emergency situations. Safety Science, 111, 144-153. https://doi.org/10.1016/j. ssci.2018.07.005.

15. Nowrouzi-Kia, B., Sharma, B., Dignard, C., Kerekes, Z., Dumond, J., Li, A., \& Larivière, M. (2017). Systematic review: Lost-time injuries in the US mining industry. Occupational Medicine, 67, 442-447. https://doi.org/10.1093/occmed/kqx077.

16. Gendler, S.G., Grishina, A.M., \& Kochetkova, E.A. (2017). Optimization of expenditures for labour protection at deep mining. Eurasian Mining, 2, 35-39. https://doi. org/10.17580/em.2017.02.09.

17. Kozlov, G. V. (2017). Problems of professional suitability of miners to work as part of auxiliary mine rescue teams. Industrial safety of enterprises of the mineral resource complex in the XXI century. Vol. 1. Mining Information and Analytical Bulletin, 4(5/1), 366-373.

18. Pika, A., ter Hofstede, A.H.M., Perrons, R.K., Grossmann, G., Stumptner, M., \& Cooley, J. (2021). Using big data to improve safety performance: an application of process mining to enhance data visualisation. Big Data Research, 25, 100210. https://doi.org/10.1016/i.bdr.2021.100210.
19. Ballesteros, M. F., Sumner, S.A., Law, R., Wolkin, A., \& Jones, C. (2020). Advancing injury and violence prevention through data science. Journal of Safety Research, 73, 189-193. https://doi.org/10.1016/j.jsr.2020.02.018.

20. Li, J., Qin, Y., Yang, L., Wang, Z., Han, K., \& Guan, C. (2021). A simulation experiment study to examine the effects of noise on miners' safety behaviour in underground coal mines. BMC Public Health, 21(1), 324. https://doi. org/10.1186/s12889-021-10354-2.

\section{Принципи відбору, навчання й підтримки навичок безпечної роботи персоналу для підприємств гірничодобувної галузі}

\section{С. Г. Гендлер ${ }^{1}$, М. В. Туманов ${ }^{1}$, Л. Ю. Левін ${ }^{2}$}

1 - Санкт-Петербурзький гірничий університет, м. СанктПетербург, Російська Федерація, e-mail: gendler_sg@nuos. pro

2 - Гірничий інститут Уральського відділення Російської академії наук, м. Перм, Російська Федерація

Мета. Зниження ризиків аварійності та травматизму на основі здійснення профвідбору персоналу для подальшої роботи на підприємствах гірничодобувної промисловості, а також навчання й підтримка у нього навичок безпечної роботи.

Методика. Для вирішення проблем, що розглядаються у роботі, були використані: аналіз інформації із науково-технічних джерел про вплив психофізіологічних факторів на виробничий травматизм; кореляційно-регресійний аналіз статистичних даних по виробничому травматизму; експериментальні дослідження ефективності роботи гірників у лабораторних і шахтних умовах при різних фізичних навантаженнях.

Результати. У роботі обгрунтовується роль і необхідність проведення процедур професійного психофізіологічного відбору працівників гірничодобувних підприємств, моніторингу їх функціонального стану. Запропонована методологія процедур професійного психофізіологічного відбору, інноваційного навчання й поведінкового аудиту з метою підвищення захищеності працівників від травм. Вивчені інноваційні способи навчання й підтримки навичок безпечної роботи гірників. Досліджена роль сучасних гаджетів із встановленими додатками для оцінки тяжкості фізичної роботи за показником частоти серцевих скорочень.

Наукова новизна. Новизна даного дослідження полягає в обгрунтуванні комплексного підходу до превентивного попередження виробничого травматизму в гірничодобувній галузі на етапах відбору персоналу, його навчання й подальшого контролю наслідків виробничої діяльності.

Практична значимість. Полягає в розробці принципів відбору, навчання й підтримки навичок безпечної роботи персоналу для підприємств гірничодобувної галузі.

Ключові слова: людський фактор, функціональний стан, професійний відбір, навчання персоналу, ризик травматизму, профілактика аварійності, поведінковий аудит

\section{Принципы отбора, обучения и поддержания навыков безопасной работы персонала для предприятий горнодобывающей отрасли}

\section{С. Г. Гендлер ${ }^{1}$, М. В. Туманов ${ }^{1}$, Л. Ю. Левин ${ }^{2}$}

1 - Санкт-Петербургский горный университет, г. СанктПетербург, Российская Федерация, e-mail: gendler_sg@ nuos.pro

2 - Горный институт Уральского отделения Российской академии наук, г. Пермь, Российская Федерация 
Цель. Снижение рисков аварийности и травматизма на основе осуществления профотбора персонала для последующей работы на предприятиях горнодобывающей промышленности, а также обучения и поддержание у него навыков безопасной работы.

Методика. Для решения проблем, рассматриваемых в работе, были использованы: анализ информации из научно-технических источников о влиянии психофизиологических факторов на производственный травматизм; корреляционно-регрессионный анализ статистических данных по производственному травматизму; экспериментальные исследования эффективности работы горнорабочих в лабораторных и шахтных условиях при различных физических нагрузках.

Результаты. В работе обосновывается роль и необходимость проведения процедур профессионального психофизиологического отбора работников горнодобывающих предприятий, мониторинга их функционального состояния. Предложена методология процедур профессионального психофизиологического отбора, инновационного обучения и поведенческого аудита в целях повышения защищенности работников от травм. Изучены инновационные способы обучения и поддержания навыков безопасной работы горнорабочих. Исследована роль современных гаджетов с установленными приложениями для оценки тяжести физической работы по показателю частоты сердечных сокращений.

Научная новизна. Новизна данного исследования состоит в обосновании комплексного подхода к превентивному предупреждению производственного травматизма в горнодобывающей отрасли на этапах отбора персонала, его обучения и дальнейшего контроля последствий производственной деятельности.

Практическая значимость. Заключается в разработке принципов отбора, обучения и поддержания навыков безопасной работы персонала для предприятий горнодобывающей отрасли.

Ключевые слова: человеческий фактор, функциональное состояние, профессиональный отбор, обучение персонала, риск травматизма, профилактика аварийности, поведенческий аудит

Recommended for publication by I.D. Tiurpin, Doctor of Technical Sciences. The manuscript was submitted 25.12.20. 